\title{
METODE JIGSAW SOLUSI ALTERNATIF DALAM MENINGKATKAN MOTIVASI BELAJAR DAN PRESTASI BELAJAR SISWA Ani Mardliyah
}

\author{
ISNU (Ikatan Sarjana Nahdlatul Ulama), \\ Jawa Tengah, Indonesia. \\ El.manun@yahoo.co.id
}

\begin{abstract}
Abstrak
Artikel ini bertujuan untuk mengetahui motivasi belajar siswa pada mata pelajaran Al-Qur'an hadits dengan fokus materi Q.S al-Lahab dan an-Nashr melalui metode pembelajaran Jigsaw di MTsN 02 Semarang. Penelitian ini memberikan informasi sebagai masukan untuk pengembangan model pembelajaran Jigsaw pada materi Q.S al-Lahab. Di samping itu, penelitian ini juga memberikan pelajaran yang lebih bervariatif, terutama bagi siswa MTs N 02 Semarang khususnya agar lebih tertarik untuk aktif dalam belajar. Karena penggunaaan variasi mengajar melalui metode jigsaw membuat para siswa menjadi lebih termotivasi untuk belajar dan melatih kerjasama serta melatih kemandirian siswa dalam belajar. Hasil penelitian ini dapat digunakan sebagai bahan masukan (memberikan konstribusi) yang berarti bagi upaya peningkatan mutu pelajaran Al-Qur'an hadits khususnya peningkatan hasil belajar siswa. Selain itu juga dapat dipergunakan sebagai bahan atau masukan dalam mengajarkan $\mathrm{Al}$-Qur'an hadits kepada anak didik dalam meningkatkan keaktifan siswa dalam mengikuti kegiatan belajar mengajar.
\end{abstract}

Kata kunci: Jigsaw, al-qur'an, hadits, motivasi, belajar

\begin{abstract}
This article aims to determine students' motivation on the subjects of the Qur'an hadits with a focus on material Q.S al-Lahab and anNasr through Jigsaw learning method in MTsN 02 Semarang. The
\end{abstract}


study provides information as an input for the development of Jigsaw learning model on material of Q.S al-Lahab. In addition, this study also provides lessons more varied, especially for students of MTs N 02 Semarang in particular to be more interested in active learning. Because the use of variety of teaching through jigsaw method makes students become more motivated to learn and practice cooperation and to train students' independence in learning. The results of this study can be used as an input (contribution) that means for improving the quality of learning the Qur'an hadits in particular improving student learning outcomes. It also can be used as an ingredient or input in the hadith teaches the Qur'an to students in improving students' activeness in following the teaching and learning activities.

Keywords: Jigsaw, Al-Qur'an, hadist, learning, motivation

\section{A. Pendahuluan}

Pendidikan agama Islam dialami oleh siswa di sekolah dimulai dari tahapan kognisi, yakni pengetahuan dan pemahaman siswa terhadap ajaran dan nila-nilai yang terkandung dalam ajaran Islam, untuk selanjutnya menuju ke tahapan afeksi yakni terjadinya proses internalisasi ajaran dan nilai agama ke dalam diri siswa, dalam arti menghayati dan menyakininya. Pada tahapan afeksi ini terkait erat dengan kognisi, dalam arti penghayatan dan keyakinan siswa menjadi kokoh jika dilandasi oleh pengetahuan dan pemahamannya terhadap ajaran dan nilai agama Islam, melalui tahapan afeksi tersebut diharapkan dapat tumbuh motivasi dalam diri siswa dan bergerak untuk mengamalkan dan menaati ajaran Islam (tahapan psikomotor) yang telah diinternalisasikan dalam dirinya, dengan demikian, akan terbentuk manusia muslim yang beriman, bertaqwa dan berakhlak mulia (Muhaimin, 2001: 79).

Guru secara khusus sering di istilahkan sebagai "jiwa bagi tubuh" pendidikan. Pendidikan tidak akan berarti apa-apa tanpa kehadiran guru, apapun model kurikulum dan paradigma pendidikan yang berlaku, gurulah yang pada akhirnya yang menentukan tercapainya program tersebut. Namun demikian peran tenaga kependidikan lainnya tidak kalah pentingnya, bahkan kemampuan kerja kolektif yang ditujukan kepada semua elemen yang terkait menjadi kunci suksesnya proses pendidikan disebuah madrasah (Rahim, 2005: 3). 
Pembelajaran sangat ditentukan oleh kiat masing-masing guru di kelas, tenaga pengajar yang profesional akan terukur dari sejauh mana menguasai kelas yang diasuhnya, hingga mengantarkan peserta didiknya mencapai hasil yang optimal. Dalam pandangan psikologi belajar, keberhasilan belajar itu lebih banyak ditentukan oleh tenaga pengajarnya, hal ini disebabkan tenaga pengajar selain sebagai orang yang berperan dalam proses transformasi pengetahuan dan keterampilan, juga sebagai pemandu segenap proses pembelajaran. Disinilah sebuah peristiwa belajar dapat berlangsung, persiapan dan pertumbuhan itu diarahkan agar ia menjadi manusia yang berdayaguna dan berhasil bermanfaat bagi dirinya sendiri, dan bagi umatnya serta dapat memperoleh suatu kehidupan yang layak dan sempurna (Falah, 2010: 100). Seorang guru dalam aktifitasnya mengajar sudah sewajarnya apabila memiliki kompetensi profesional. Kompetensi profesional meliputi: kemampuan menguasai bahan atau materi bidang studi, mampu mengelola program belajar mengajar, mampu mengelola kelas, mampu menilai hasil belajar mengajar, mampu menggunakan sumber atau media pembelajaran, menguasai metode berfikir, memiliki wawasan penelitian sederhana untuk keperluan pembelajaran, menggunakan waktu secara tepat dan cepat (Falah, 2010: 105).

Penyelenggaraan proses kegiatan belajar mengajar di MTsN 02 Semarang ada sebagian guru ketika mengajar tidak diikuti dengan pemilihan metode mengajar, media pembelajaran dan strategi mengajar, akibatnya siswa tidak termotivasi dalam proses pembelajaran sehingga prestasinya pun menurun. Menurut Bapak M.Syaifudin guru mata pelajaran al-Qur'an Hadits kelas VIID menyatakan bahwa nilai hasil belajar mata pelajaran al-Qur'an Hadits masih ada 19 siswa dari 42 siswa yang mendapatkan nilai dibawah Kriteria Ketuntasan Minimal (KKM). KKM al-Qur'an Hadits pada kelas VIID di MTsN 02 Semarang adalah 70. Pada sisi lain motivasi siswa di sekolah rata2 dalam menerima pelajaran malas (kurang bergairah), yang sungguh-sungguh dalam kegiatan belajar mengajar adalah 22 anak sedangkan sisanya 20 anak kurang memperhatikan pelajaran sehingga kurang mampu memahami materi pada mata pelajaran al-Qur'an Hadits (Syaifudin, 2013).

Penggunaan dari sebuah metode yang tepat untuk materi yang 
akan disampaikan, dapat memberi motivasi pada diri siswa pada saat menerima materi pelajaran. Siswa dengan sendirinya akan termotivasi jika materi yang akan disampaikan menarik dan guru tidak perlu lagi mendorong siswanya untuk belajar, karena mereka sendiri telah termotivasi untuk mempelajari materi yang akan disampaikan. Oleh karena itu, penggunaan metode yang tepat itu sangat mempengaruhi kepada siswa untuk meningkatkan prestasi belajar. Dan guru juga sangat berperan dalam meningkatkan motivasi dan prestasi belajar siswa melalui metode-metode yang digunakan dalam penyampaian materi pelajaran termasuk materi Q.S al-Lahab dan Q.S an-Nashr.

Guru Al-Qur'an hadits yang memiliki kompetensi profesional memiliki kemampuan seperti mengelola program belajar mangajar, mampu mengelola kelas, menilai hasil belajar, menggunakan sumber atau media pembelajaran, termasuk kemampuan dalam menggunakan metode pembelajaran "Jigsaw" yang diharapkan dapat meningkatkan motivasi dan hasil belajar siswa sehingga dapat juga meningkatkan pemahaman siswa terhadap materi pembelajaran.

Guru harus dituntut untuk mengkritisi dalam memilih dan menerapkan pendekatan pembelajaran yang tepat sesuai dengan karakteristik siswa dan materi ajar, pendekatan pembelajaran yang diharapkan siswa mampu menciptakan pembelajaran yang efektif serta mampu meningkatkan motivasi dan hasil belajar siswa adalah dengan pembelajaran Jigsaw, pendekatan ini dapat diterapkan pada semua mata pelajaran dan jenjang pendidikan termasuk ditingkat Madrasah Tsanawiyah (MTs).

Berdasarkan uraian diatas, Peneliti bermaksud mengadakan penelitian dengan judul "Upaya Peningkatan Motivasi dan Prestasi Belajar Al-Qur'an Hadits Materi Q.S al-Lahab Dan an-Nashr Melalui Metode Pembelajaran Jigsaw Pada Siswa Kelas VII D di MTs Negeri 02 Semarang".

Penelitian ini merupakan penelitian tindakan kelas. Adapun tahapan-tahapan yang dilakukan dalam tindakan kelas ini menggunakan model yang digunakan oleh Kurt Lewin. Tahapantahapan penelitian tindakan kelas ini dibagi menjadi 4 yaitu: a) Perencanaan (Planning), b) Aksi/tindakan (Acting), c) Observasi (Observing), d) Refleksi (Reflekction) 
Adapun pelaksanaan tindakan kelas meliputi 3 siklus yan terdiri dari: a) Pra Siklus, b) Siklus 1, c) Siklus 2. Siklus kegiatan ini meliputi 2 siklus masing-masing siklus dilaksanakan dengan empat tahap yaitu tahap perencanaan, tindakan, observasi, dan refleksi, sebagaimana gambar kegiatan siklus berikut ini:

Gambar 1 tentang sistematika siklus

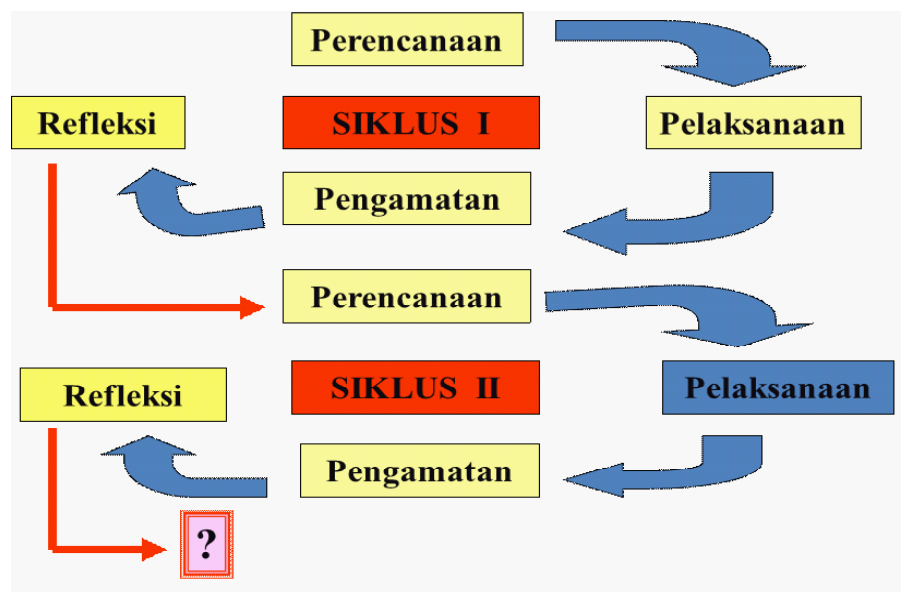

\section{a. PraSiklus}

Sebelum melakukan penelitian, penulis mempersiapkan segala sesuatu yang berkaitan dengan pelaksanaan penelitian, diantaranya menyusun rencana pelaksanaan pembelajaran (RPP) untuk tiap siklus, rancangan ini disempurnakan kembali pada awal siklus 1 dan 2 setelah mendapat umpan balik, analisis, dan refleksi siklus 1 dan II. Selain hal diatas peneliti membuat instrumen sebagai alat pengumpulan data berupa tugas yang diberikan kepada peserta didik.

\section{b. Siklus Satu}

1) Tahap Perencanaan

Dalam tahap perencanaan penulis membuat perencanaan dengan membuat instrumen yang akan dipakai dalam pelaksanaan pembelajaran yaitu, berupa rencana pembelajaran, lembar pengamatan, dan menyiapkan sumber 
belajar sebagai alat bantu dalam proses pembelajaran AlQur'an hadits. (RPP Terlampir).

2) Tahap Pelaksanaan

Pada pelaksanaan siklus 1 yang dilaksanakan pada hari kamis, 16 Mei 2013 dengan dibantu oleh guru pamong dan dosen pembimbing PTK sekaligus sebagai pengamat dalam proses pembelajaran, penulis melakukan kegiatan pembelajaran Q.S al-Lahab dengan menggunakan metode Jigsaw dengan langkah-langkah sebagai berikut:

a. Guru membagi siswa menjadi 4 kelompok kerja, tiap kelompok 10 siswa.

b. Guru menyajikan pembelajaran dengan penemuan konsep metode Jigsaw yang sederhana.

c. Setiap kelompok mendapatkan tugas membaca, memahami dan mendiskusikan serta membuat ringkasan materi pelajaran yang berbeda, contoh: kelompok 1 membahas tentang terjemahan mufrodat Q.S al-Lahab, kelompok 2 membahas tentang terjemahan mujmal Q.S al-Lahab, kelompok 3 membahas tentang Asbabun nuzulnya, kelompok 4 membahas tentang isi kandungannya.

d. Setiap kelompok mengirimkan anggota ke kelompok lain untuk menyampaikan apa yang telah mereka pelajari dikelompoknya untuk mempresentasikan hasil diskusinya.

e. Guru menyuruh peserta didik untuk kembali pada pada suasana kelas seperti semula kemudian guru menanyakan seandainya ada persoalan persoalan yang tidak dapat dipecahkan dalam kelompok

f. Guru melakukan kesimpulan, klarifikasi dan tindak lanjut.

3) Tahap Obsevasi

Pada tahap ini guru melakukan pengamatan secara langsung ke siswa yang meliputi kesungguhan siswa dalam pembelajaran, motivasi siswa dalam mengajukan pertanyaan dan Antusias siswa dalam pembelajaran, kekeompakan siswa dalam mengerjakan tugas kelompok, dan ketelitian siswa dalam mengerjakan tugas dan latihan, dalam tahap ini data 
yang telah terkumpul kemudian dianalisis dan hasilnya dapat digunakan sebagai gambaran pelaksanaan perbaikan pada pembelajaran pada siklus II ( Lembar observasi terlampir).

4) Tahap Refleksi

Tahap refleksi ini dilaksanakan setelah pembelajaran berlangsung, instumen yang digunakan adalah tes formatif, dibantu oleh teman sejawat, dengan melihat tes formatif yang telah diberikan, maka penulis mengadakan refleksi sebagai berikut:

a. Peserta didik ada yang kurang menguasai materi Q.S. alLahab.

b. Teknik yang digunakan dalam pembelajaran belum dipraktikkan secara maksimal.

c. Peserta didik dalam menerima pelajaran kurang sungguhsungguh.

d. Guru mengadakan kegiatan pembelajaran pengayaan atau remedial berupa latihan-latihan soal kepada siswa untuk mengetahui sejauhmana pemahaman terhadap materi.

c. Siklus Dua

1) Tahap Perencanaan

Identifikasi dan perumusan masalah pada siklus 1Menyempurnakan perencanaan untuk pelaksaaan pembelajaran seperti siklus 1 dengan memberi perhatian pada permasalahan yang telah ditemukan pada siklus 1 .

2) Tahap Pelaksanaan

Tahap pelaksanaan siklus II ini dilaksnakan pada tanggal 23 Mei 2013 dengan dibantu teman sejawat sekaligus sebagai pengamat dalam pembelajaran, pada pelaksanaan siklus II, dilakukan sebagai upaya peningkatan kemampuan hasil belajar pada materi Q.S al-Lahab melalui model Pembelajaran Jigsaw bagi siswa kelas V11 D di MTs N 02 Semarang yang didalamnya mengadakan serangkaian kegiatan sebagai berikut:

a. Guru melaksanakan pembelajaran seperti pada siklus 1 
b. Memberi kesempatan kepada siswa untuk menemukan dan menerapkan idenya sendiri. disini siswa aktif dengan mengajukan pertanyaan dan siswa yang lain menjawab pertanyaan tersebut sedangkan guru hanya membimbing.

c. Guru meningkatkan kegiatan yang belum mendukung keaktifan dan motivasi dalam mengikuti kegiatan pembelajaran materi Q.S al-Lahab.

d. Menyadarkan siswa agar menerapkan strategi mereka sendiri dalam belajar artinya siswa mampu menyerap dan mengaplikasikan materi pelajaran dalam dunia nyata.

3) Tahap Observasi.

Tahap ini guru memberikan penjelasan dari awal sampai terjadinya diskusi antar siswa kemudian siswa mengerjakan soal-soal yang berhubungan dengan materi Q.S al-Lahab, tes formatif ini dilaksanakan pada kegiatan akhir sebagai bahan penulis untuk menganalisis hasil pekerjaan siswa dan mempraktikkan atau mengaplikasikan materi yang yang dipelajari dalam kehidupan sehari-hari.

4) Tahap Refleksi

Berdasarkan hasil pengamatan antara guru dengan guru pamong bahwa pada siklus kedua ini, diperoleh suatu perubahan, yakni peserta didik telah mengadakan diskusi dengan baik sehingga terdapat peningkatan motivasi dan hasil belajar materi Q.S al-Lahab.

\section{B. Pembahasan}

\section{Motivasi Belajar}

\section{a. Pengertian Motivasi}

Motivasi dari segi bahasa berasal dari bahasa Inggris motivation yang berarti alasan, daya batin dan dorongan (Echols dan Sadily, 2000: 377). Sedangkan arti motivasi secara terminologi adalah sebagai berikut:

1. Gunarsa (1978: 66): Motivasi adalah dorongan kehendak yang timbul dalam diri/jiwa manusia terjadi keadaan tidak seimbang. 
2. Nasution (1982: 76): Motivasi adalah usaha-usaha untuk menyediakan situasi atau kondisi-kondisi sehingga anak itu mau melakukannya.

Dari definisi-definisi di atas, dapat penulis simpulkan bahwa motivasi adalah usaha untuk menimbulkan kondisi-kondisi yang mengarahkan, menuntun, dan membentuk perilaku seseorang.

Berdasarkan Uraian di atas, dapat kita ketahui bahwa motif mengandung 3 unsur elemen penting, yaitu:

1. Motivasi itu mengawali terjadinya perubahan energi pada setiap diri manusia.

2. Motivasi ditandai dengan timbulnya perasaaan seseorang.

3. Motivasi ditandai dengan reaksi untuk mencapai tujuan.

Sementara itu, belajar ialah proses usaha yang dilakukan seseorang untuk memperoleh perubahan tingkah laku yang baru secara keseluruhan sebagai hasil pengalamannya sendiri dalam interaksi dengan lingkungannya. Belajar merupakan perubahan tingkah laku atau penampilan, dengan serangkaian kegiatan, misalnya dengan membaca, mengamati, mendengarkan, meniru dan lain sebagainya.

Aktivitas-aktivitas siswa yang demikian jelas, bahwa segala sesuatu yang akan siswa kerjakan pasti sesuai dengan kebutuhannya, kebutuhan itu sendiri adalah sebagai pendorong dan aktivitas belajar siswa, kebutuhan dalam hal ini adalah hasil belajar. Seluruh aktivitas siswa tujuannya untuk mendapatkan hasil belajar yang baik, setiap siswa pasti tidak ingin memperoleh hasil belajar yang jelek, oleh karena itu setiap siswa harus berlomba-lomba untuk mencapainya dengan suatu usaha yang dilakukan seoptimal mungkin untuk selalu belajar (Fathurrohman \& Sulistiyorini, 2012: 118).

Berdasarkan pengertian diatas dapat disimpulkan bahwa motivasi belajar adalah keseluruhan daya penggerak yang terdapat di dalam diri peserta diri yang menimbulkan kegiatan belajar Agama Islam dan memberikan arahan pada kegiatan belajar tersebut untuk mencapai tujuan.

\section{b. Macam-macam Motivasi}

Secara umum motivasi dibagi 2 macam yaitu motivasi intrinsik dan motivasi ekstrinsik 
1. Motivasi intrinsik adalah motivasi yang berasal dari dalam diri anak sendiri, biasanya dorongan ini datang dari "hati sanubari", umumnya karena kesadaran akan pentingnya sesuatu, atau dapat juga karena bakat apabila ada kesesuaian dengan bidang yang dipelajari. (Fathurrohman \& Sulistiyorini, 2012: 144).

2. Motivasi ekstrinsik adalah motivasi atau tenaga-tenaga pendorong yang berasal dari luar anak, motivasi ekstrinsik ini sebagai motivasi yang dihasilkan diluar perbuatan itu sendiri, misalnya dorongan yang datang dari orangtua, guru, temanteman dan anggota masyarakat yang berupa hadiah, pujian, penghargaan maupun hukuman.

\section{c. Fungsi Motivasi}

Adapun fungsi motivasi antara lain:

1. Mendorong timbulnya kelakuan atau suatu perbuatan, tanpa motivasi maka tidak akan timbul sesuatu perbuatan seperti belajar.

2. Motivasi berfungsi sebagai pengarah artinya mengarahkan perbuatan ketercapainnya tujuan yang diinginkan.

3. Motivasi berfungsi sebagai penggerak, ia sebagai mesin bagi mobil, besar kecilnya motivasi akan menetukan cepat atau lambatnya pekerjaan. (Fathurrohman \& Sulistiyorini, 2012: 151).

\section{Prestasi Belajar}

\section{a. Pengertian Prestasi Belajar}

Prestasi belajar adalah sebuah kalimat yang terdiri dari dua kata yakni prestasi dan belajar, antara kata prestasi dan belajar mempunyai arti yang berbeda, berikut ini pengertian prestasi dan belajar, menurut WJS. Poerwadarminta berpendapat bahwa prestasi adalah hasil yang telah dicapai (dilakukan, dikerjakan, dan sebagainya) (Djamarah, 1994: 20) sementara menurut Mas'ud Khasan Abdul Qahar seperti dikutip dalam bukunya prestasi belajar karangan Syaiful Bahri Djamarah bahwa prestasi adalah apa yang telah diciptakan, hasil pekerjaan, hasil yang menyenangkan hati, yang diperoleh dengan jalan keuletan kerja. (Djamarah, 1994: 21).

Adapun pengertian belajar menurut psikologi adalah suatu proses perubahan yaitu perubahan didalam tingkah laku sebagai 
hasil interaksi dengan lingkungannya dalam memenuhi kebutuhan hidupnya, perubahan-perubahan tersebut akan dinyatakan dalam seluruh aspek tingkah laku, (Purwanto, 1998: 85) jadi pengertian belajar dapat didefinisikan sebagai berikut" Belajar ialah suatu proses usaha yang dilakukan individu untuk memperoleh suatu perubahan tingkah laku yang baru secara keseluruhan sebagi hasil dari pengalaman individu itu sendiri dalam interaksi dengan lingkungan."

Menurut Sally Wehmeier dalam bukunya Oxford advanced leaner's dictionary mendefinisikan bahwa, achievement: $a$ thing that somebody has done success fully, especially using their own effort and skill. (Wehmeier, 2000: 10) (Artinya: Sesuatu yang telah dilakukan seseorang dengan sukses, khususnya menggunakan usaha dan kecakapannya sendiri).

Berangkat dari pengertian diatas bahwa, prestasi belajar dapat diartikan sebagai tingkat kemampuan aktual yang dapat diukur berupa penguasaan ilmu pengetahuan, sikap dan keterampilan sehingga hasil dari proses belajar mengajar, jadi prestasi belajar diartikan sebagai perubahan tingkah laku yang terjadi pada diri seseorang sesudah melakukan kegiatan belajar.

Perubahan yang terjadi dalam diri individu banyak sekali sifat maupun jenisnya karena itu sudah tentu tidak setiap perubahan dalam diri individu merupakan perubahan dalam arti belajar, berikut ini ciri-ciri perubahan tingkah laku dalam pengertian belajar

1. Perubahan yang terjadi secara sadar

2. Perubahan dalam belajar bersifat fungsional.

3. Perubahan dalam belajar bersifat positif aktif.

4. Perubahan dalam belajar bukan bersifat sementara.

5. Perubahan dalam belajar bertujuan dan terarah.

6. Perubahan mencakup seluruh aspek tingkah laku

Berdasarkan definisi diatas, maka dapat dijelaskan pengertian prestasi belajar adalah hasil yang telah dicapai dari suatu kegiatan yang berupa perubahan tingkah laku yang dialami subyek belajar didalam suatu interaksi dengan lingkungannya.

Sutratinah Tirtonegoro seperti dikutip dalam bukunya Belajar Pembelajaran karangan Moh. Fathurrohman bahwa prestasi belajar adalah penilaian hasil usaha kegiatan belajar yang dinyatakan dalam 
bentuk simbol, angka, huruf maupun kalimat yang mencerminkan hasil yang sudah dicapai oleh setiap anak dalam periode tertentu (Fathurrohman dan Sulistiyorini: 119).

\section{b. Faktor-faktor yang mempengaruhi prestasi belajar}

Belajar adalah suatu proses yang kompleks, karena itu prestasi belajar atau keberhasilan belajar tergantung pada faktor-faktor yang memepengaruhi sukses belajar dapat dibedakan menjadi 3 macam: yaitu faktor internal, faktor eksternal, dan faktor pendekatan belajar.

1) Faktor Internal

Faktor internal ini berasal dari dalam diri siswa sendiri meliputi 2 aspek yakni aspek fisiologis dan aspek psikologis.

a) Aspek Fisiologis

Faktor-faktor ini berkaitan dengan kesehatan badan dan kesempurnaanya, yaitu tidak mengalami cacat dan kekurangan yang dapat menjadi hambatan dalam meraih sukses dalam belajar. Misalnya kurangnya kadar makanan, beberapa penyakit kronis dan lain-lain.

b) Aspek Psikologis

Faktor yang termasuk aspek psikolgis yang dapat mempengaruhi kualitas dan kuantitas perolehan pembelajaran siswa, diantaranya:

1. intelegensi siswa

2. sikap siswa

3. bakat siswa

4. minat siswa

5. motivasi siswa (Ahmadi: 133-136).

2) Faktor Eksternal

Faktor eksternal adalah faktor dari luar siswa yang teridri dari 2 macam, yaitu:

a) Faktor Lingkungan Sosial

Yaitu lingkungan sosial sekolah seperti guru, para staf administrasi dan teman-teman sekelas dapat mempengaruhi semangat belajar, contoh pola perilaku yang baik menjadi daya pendorong kegiatan belajar siswa, disamping itu lingkungan masyarakat dan tetangga yang baik juga mempengaruhi aktivitas belajar siswa, tetapi 
lingkungan sosial yang banyak mempengaruhi kegiatan belajar adalah oarangtua dan diri sendiri.

b) Faktor Non Sosial

Faktor yang termasuk non sosial adalah gedung sekolah letaknya, tempat tinggal, keluarga, alat-alat belajar. Keadaan cuaca dan waktu belajar yang digunakan siswa, faktor-faktor ini dipandang turut menentukan tingkat keberhasilan belajar siswa. (Syah, 2010: 136)

c) Faktor Pendekatan Belajar

Yakni jenis upaya belajar siswa yang meliputi strategi dan metode yang digunakan siswa untuk melakukan kegiatan pembelajaran materi-materi pelajaran.

Pendekatan belajar, seperti yang telah diuraikan sebelumnya, dapat dipahami keefektifan segala cara atau strategi yang digunakan siswa dalam menunjang keefektifan dan efesiensi proses materi belajar tertentu. Strategi dalam hal ini bararti seperangkat langkah opersional yang direkayasa sedemikian rupa untuk memecahkan masalah atau tujuan pembelajaran tertentu. (Syah, 2010: 136)

\section{Materi Qur'an Hadits}

\section{a. Al-Qur'an surat al-Lahab}

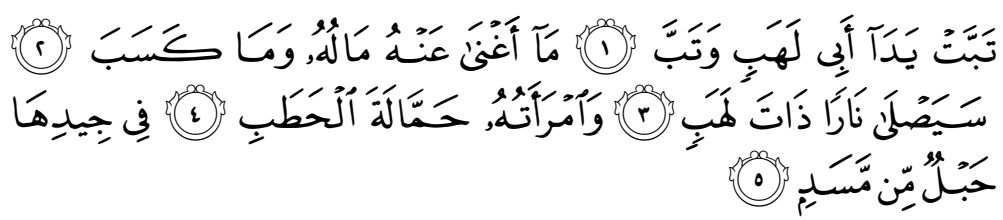

"Binasalah kedua tangan Abu Lahab dan sesungguhnya dia akan binasa. Tidaklah berfaedah kepadanya harta bendanya dan apa yang ia usahakan. Kelak dia akan masuk ke dalam api yang bergejolak. Dan (begitu pula) istrinya, pembawa kayu bakar. Yang di lehernya ada tali dari sabut." (Departemen Agama, 2000: 1116)

1) Penjelasan Q.S. al-Lahab

a) Nama Surah

Surah ini terkenal dengan nama al-Lahab diambil dari ayat pertama. Nama lain al Masad (sabut penjerat), Tabbat (binasalah). Termasuk jenis surah Makiyah, surat ke-6 dari segi tertib turunnya dan ke-111 dari segi tertib penulisannya.

b) Tema Utama 
Membicarakan tentang kebinasaan yang akan dialami oleh salah seorang tokoh utama kaum musyrikin yaitu Abu Lahab. Uraian menyangkut kebinasaan istrinya adalah bagian dari siksa yang akan dialami oleh Abu lahab itu.

\section{c) Asbābul Nuzū}

Dalam suatu riwayat dikemukakan bahwa suatu ketika Rasulallah saw. naik ke bukit Shafa ambil berseru: "Mari kumpul pada pagi hari ini!” Maka berkumpulah kaum Quraisy. Rasulullah saw..bersabda: "Bagaimana pendapat kalian, seandainya aku beri tahu bahwa musuh akan datang besok pagi atau petang, apakah kalian percaya kepadaku?" Kaum Quraisy menjawab: "pasti kami percaya”. Rasulallah saw. bersabda: "Aku peringatkan bahwa siksa Allah yang dahsyat akan datang”. Berkata Abu Lahab: "Celaka engkau! Apakah hanya untuk ini, engkau kumpulkan kami?” Maka turunlah ayat ini berkenaan dengan peristiwa itu yang melukiskan bahwa kecelakaan itu akan terkena kepada orang yang memfitnah dan menghalanghalangi agama Allah.

d) Kandungan Isi

Ayat 1 dan 2, ayat pertama merupakan do'a untuk Abu Lahab agar merugi dan celaka. Kebinasaan bukan hanya pada kedua belah tangannya, bahkan dirinya sendiri, rohani dan jasmaninya pun akan binasa. Apa yang direncanakannya dalam menghalangi dakwah Nabi SAW. tidaklah akan ada yang berhasil. Abu Lahab adalah gelar Abdul Uzza ibn Abul Muttalib. Ia adalah paman Nabi Muhammad SAW. Dia dijuluki Abu Lahab (bapaknya jilatan api) karena pipinya kemerahmerahan, atau sebagai isyarat bahwa kelak dia akan masuk neraka.

Ayat kedua menginformasikan Abu Lahab tidak ada peluang untuk selamat. Sungguh binasa kedua tangannya, harta benda dan segala usahanya tidak dapat menyelamatkan dari kebinasaan. Ayat ke 3, 4 dan 5, Kelak Abu Lahab pasti binasa disiksa di api neraka yang apinya berkobar-kobar dengan ganasnya. Neraka tersebut tidak hanya disediakan untuk Abu lahab, tetapi juga untuk kaum kafir yang menentang Nabi SAW. Kebinasaan juga menimpa istri Abu Lahab, yaitu Urwah binti Harb, saudara perempuan Abu Safyan bin Harb. Dia digelari Ummu Jamil. 
Kalimat (حمالة الحطب) dipahami dalam arti pembawa isu dan fitnah, yang bertujuan melecehkan Nabi Saw. dan memecah belah kaum muslimin. Atau sebagai ungkapan penghinaan kepadanya yang kaya raya.

Surah Al Lahab ditutup dengan pernyataan, betapa hina Abu Lahab. Kelak dia di neraka jahannam. Istri Abu Lahab wafat dalam kemusyrikan sehingga ayat di atas dapat dinilai sebagai salah satu ayat yang berbicara tentang gaib yang telah terbukti. (Ibrohim dan Darsono, 2009: 78-79).

e) Q.S an-Nashr

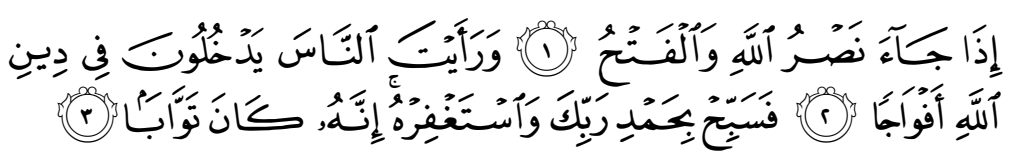

"Apabila telah datang pertolongan Allah dan kemenangan. Dan kamu lihat manusia masuk agama Allah dengan berbondong-bondong, maka bertasbihlah dengan memuji tuhanmu dan mohonlah ampun kepadaNya, sesungguhnya dia maha penerima taubat." (Departemen Agama, 2000: 1116)

2) Penjelasan Q.S an-Nashr

a) Nama surah

Surat ini terkenal dengan nama an-Nashr. Pada masa lampau terkenal idza jaa nashrullahi wal fath sesuai bunyi ayat pertama. Ada pula yang memahami at-Taudi (perpisahan). Termasuk jenis surah madaniyah, surah ke 103 dari segi tertib turunnya, dan surah ke 110 dari segi tertib penulisannya.

b) Tema utama

Tema utamanya adalah berita gembira tentang kemenangan yang akan diraih oleh Rasul SAW. dan berbondong-bondongnya masyarakat memeluk agama Islam. Disisi lain mengisyaratkan selesainya tugas Rasul Saw. Dengan demikian surah ini menginformasikan dekatnya ajal Rasul Saw.

c) Asbābun nuzū

Dalam suatu riwayat dikemukakan bahwa ketika Rasulallah SAW. masuk kota Makah pada waktu fathu makah, Khalid bin Walid diperintahkan memasuki kota Makah dari jurusan dataran rendah 
untuk menggempur pasukan quraisy (yang menyerangnya) serta merampas senjatanya. Setelah memperoleh kemenangan. Maka berbondong-bondonglah kaum quraisy masuk Islam. Ayat ini (Q.S. an-Nashr 1-3) turun berkenaan dengan peristiwa itu. Sebagai perintah untuk memui syukur dengan me-Mahasucikan Allah atas kemenangannya dan meminta ampun atas segala kesalahan.

d) Kandungan isi

Ayat pertama merupakan informasi datangnya kemenangan yang akan diraih oleh kaum muslimin. Kemenangan yang di maksud adalah ditaklukkannya kota makah (fathu makah). Kemenangan Rasul SAW. dan kaum muslimin diawali dengan ditaklukkannya kota Makah, pada bulan Ramadhan tahun ke-8 hijriyah (Desember $630 \mathrm{M}$ ). Rasulallah SAW. berhasil memasuki kota Makah tanpa pertumpahan darah.

Ayat 2 menjelaskan tentang dampak ditaklukkannya kota Makah. Pembebasan kota Makah memberi pengaruh yang besar dalam kehidupan agama dan politik. Pengaruh tersebut antara lain banyaknya manusia masuk Islam dan bernaung di bawah panji Nabi SAW. secara berbondog-bondong. Hal itu terbukti banyaknya utusanutusan yang datang ke Madinah pada tahun ke-9 Hijriyah, untuk mewakili golongannya menyatakan keislamannya. Para ahli sejarah menguraikan, "Rasulullah SAW. tidak akan meniggalkan dunia fana ini, kecuali seluruh orang arab di jazirah Arabia dan Yaman telah masuk Islam.

Ayat ke-3 menjelaskan, jika kemenangan sudah nyata, Mahasucikanlah dan agungkanlah Tuhanmu. Sebab Tuhan tidak akan sekali-kali melalaikan kebenaran dan memenangkan kebatilan. Ayat ke-3 ditutup dengan perintah memohon ampun dan bertobat kepada Allah SWT. Karena sebelum kemenangan itu diraih sempat terjadi goncangan-goncangan hati, karena terlambatnya realisasi janji pertolongan Allah SWT. Karena itu patutlah dilakukan istighfar dari kekurangan di dalam memuji Allah dan mensyukurinya. (Ibrohim dan Darsono, 2009: 82-84.) 


\section{Metode Pembelajaran Jigsaw}

\section{a. Pengertian Metode Jigsaw}

Dari sisi etimologi Jigsaw berasal dari bahasa Inggris yaitu gergaji ukir dan ada juga yang menyebutnya dengan istilah puzzle, yaitu sebuah teka teki yang menyusun potongan gambar. Jadi, pembelajaran metode Jigsaw ini diartikan dengan mengambil pola cara bekerja sebuah gergaji (jigsaw), yaitu siswa melakukan sesuatu kegiatan belajar dengan cara bekerja sama dengan siswa lain untuk mencapai tujuan bersama.

Metode pembelajaran Jigsaw merupakan sebuah teknik yang dipakai secara luas yang memiliki kesamaan dengan teknik "pertukaran dari kelompok ke kelompok" (group-to-group exchange) dengan suatu perbedaan penting yakni setiap peserta didik mengajarkan sesuatu (Silberman, 2007: 168). Metode ini juga merupakan alternatif yang menarik bila ada materi belajar yang bisa disegmentasikan atau dibagi-bagi dan bagian-bagiannya harus diajarkan secara berurutan, tiap siswa mempelajari sesuatu yang bila digabungkan dengan materi yang dipelajari oleh siswa lain membentuk kumpulan pengetahuan atau keterampilan yang padu (Silberman, 1996: 192).

Metode pembelajaran Jigsaw telah dikembangkan dan diuji coba oleh Elliot Aroson dan teman-teman dari Universitas Texas, dan diadopsi oleh Slavin dan teman-teman di Universitas John Hopkins (Trianto, 2010: 73).

\section{b. Tujuan Metode Jigsaw}

Metode yang dikembangkan oleh Elliot Aronson dkk dari Universitas Texas yang kemudian diadaptasi oleh Slavin dkk ini mempunyai tujuan:

1. Mengembangkan kerja sama tim (kelompok)

2. Mengasah keterampilan belajar kooperatif

3. Menguasai pengetahuan secara mendalam yang tidak bisa diperoleh jika mempelajarinya sendirian.

\section{c. Langkah Pelaksanaan Metode Jigsaw}

Berikut ini langkah-langkah metode jigsaw, Diantaranya:

1. Guru membagi topik yang besar menjadi beberapa subtopik. 
2. Siswa dibagi ke dalam kelompok belajar kooperatif (kelompok awal) yang terdiri dari 4-6 orang siswa dan setiap anggotanya bertanggung jawab terhadap penguasaan setiap subtopik yang ditugaskan guru dengan sebaik-baiknya.

3. Siswa dari masing-masing kelompok yang bertanggung jawab terhadap subtopik yang sama kemudian berpindah ke "kelompok jigsaw" dimana anggotanya berasal dari kelompok lain yang telah menguasai bagian tugas yang berbeda.

4. Di dalam kelompok jigsaw ini, para siswa bekerja sama untuk menyelesaikan tugas kooperatifnya dalam: a) Belajar dan menjadi ahli dalam subtopik bagiannya; a) Merencanakan bagaimana mengajarkan subtopik bagiannya kepada anggota kelompoknya semula.

5. Setelah itu siswa tersebut kembali lagi ke kelompok masingmasing (kelompok awal) sebagai "ahli" dalam subtopiknya dan mengajarkan informasi/pengetahuan yang baru mereka pelajari dalam kelompok "Jigsaw" tadi kepada temannya.

6. Ahli di dalam subtopik lainnya juga berbuat sama sehingga seluruh siswa bertanggung jawab untuk menunjukkan penguasaannya terhadap seluruh materi yang ditugaskan oleh guru. (Silberman, 1996: 193-194.)

\section{Prosedur penelitian}

Penelitian ini merupakan penelitian tindakan kelas. Adapun tahapan-tahapan yang dilakukan dalam tindakan kelas ini menggunakan model yang digunakan oleh Kurt Lewin. Tahapantahapan penelitian tindakan kelas ini dibagi menjadi 4 yaitu:

1. Perencanaan (Planning)

2. Aksi/tindakan (Acting)

3. Observasi (Observing)

4. Refleksi (Reflekction)

Adapun pelaksanaan tindakan kelas meliputi 3 siklus yan terdiri dari:

1. Pra Siklus

2. Siklus 1

3. Siklus 2

4. Siklus kegiatan 
Penelitian ini merupakan penelitian tindakan yang dilaksanakan didalam Kelas atau biasa disebut Classroom Action Research yang bertujuan memecahkan masalah-masalah dalam pembelajaran di Kelas, khususnya materi pada Q.S al-Lahab, Penelitian tindakan Kelas ini bersifat partisipatif karena melibatkan peneliti sebagai pelaku dalam proses pembelajaran dan kolaboratif karena melibatkan teman sejawat (kolaborator) untuk membantu pengamatan terhadap pelaksanaan proses pembelajaran.

Adapun langkah-langkah dalam siklus kegiatan ini adalah:

\section{Pra Siklus}

Sebelum melakukan penelitian, penulis mempersiapkan segala sesuatu yang berkaitan dengan pelaksanaan penelitian, antara lain :

a. Menyusun rencana pelaksanaan pembelajaran (RPP) untuk tiap siklus, rancangan ini disempurnakan kembali pada awal siklus 1 dan 2 setelah mendapat umpan balik, analisis, dan refleksi siklus 1 dan II.

b. Membuat instrumen sebagai alat pengumpulan data berupa tugas yang diberikan kepada peserta didik.

Siklus kegiatan ini meliputi 2 siklus masing-masing siklus dilaksanakan dengan empat tahap yaitu tahap perencanaan, tindakan, observasi, dan refleksi.

\section{Siklus Satu}

a) Tahap Perencanaan

Dalam tahap perencanaan penulis membuat perencanaan dengan membuat instrumen yang akan dipakai dalam pelaksanaan pembelajaran yaitu, berupa rencana pembelajaran, lembar pengamatan, dan menyiapkan sumber belajar sebagai alat bantu dalam proses pembelajaran Al-Qur'an hadits. (RPP Terlampir).

b) Tahap Pelaksanaan

Pada pelaksanaan siklus 1 yang dilaksanakan pada hari kamis, 16 Mei 2013 dengan dibantu oleh guru pamong dan dosen pembimbing PTK sekaligus sebagai pengamat 
dalam proses pembelajaran, penulis melakukan kegiatan pembelajaran Q.S al-Lahab dengan menggunakan metode Jigsaw dengan langkah-langkah sebagai berikut:

a. Guru membagi siswa menjadi 4 kelompok kerja, tiap kelompok 10 siswa.

b. Guru menyajikan pembelajaran dengan penemuan konsep metode Jigsaw yang sederhana.

c. Setiap kelompok mendapatkan tugas membaca, memahami dan mendiskusikan serta membuat ringkasan materi pelajaran yang berbeda, contoh: kelompok 1 membahas tentang terjemahan mufrodat Q.S al-Lahab, kelompok 2 membahas tentang terjemahan mujmal Q.S alLahab, kelompok 3 membahas tentang Asbabun nuzulnya, kelompok 4 membahas tentang isi kandungannya.

d. Setiap kelompok mengirimkan anggota ke kelompok lain untuk menyampaikan apa yang telah mereka pelajari dikelompoknya untuk mempresentasikan hasil diskusinya.

e. Guru menyuruh peserta didik untuk kembali pada pada suasana kelas seperti semula kemudian guru menanyakan seandainya ada persoalan persoalan yang tidak dapat dipecahkan dalam kelompok

f. Guru melakukan kesimpulan, klarifikasi dan tindak lanjut.

c) Tahap Obsevasi

Pada tahap ini guru melakukan pengamatan secara langsung ke siswa yang meliputi kesungguhan siswa dalam pembelajaran, motivasi siswa dalam mengajukan pertanyaan dan Antusias siswa dalam pembelajaran, kekeompakan siswa dalam mengerjakan tugas kelompok, dan ketelitian siswa dalam mengerjakan tugas dan latihan, dalam tahap ini data yang telah terkumpul kemudian dianalisis dan hasilnya dapat digunakan sebagai gambaran pelaksanaan perbaikan pada pembelajaran pada siklus II ( Lembar observasi terlampir). 
d) Tahap Refleksi

Tahap refleksi ini dilaksanakan setelah pembelajaran berlangsung, instumen yang digunakan adalah tes formatif, dibantu oleh teman sejawat, dengan melihat tes formatif yang telah diberikan, maka penulis mengadakan refleksi sebagai berikut:

a. Peserta didik ada yang kurang menguasai materi Q.S. alLahab.

b. Teknik yang digunakan dalam pembelajaran belum dipraktikkan secara maksimal.

c. Peserta didik dalam menerima pelajaran kurang sungguhsungguh.

d. Guru mengadakan kegiatan pembelajaran pengayaan atau remedial berupa latihan-latihan soal kepada siswa untuk mengetahui sejauhmana pemahaman terhadap materi.

\section{Siklus Dua}

a) Tahap Perencanaan

a. Identifikasi dan perumusan masalah pada siklus 1

b. Menyempurnakan perencanaan untuk pelaksaaan pembelajaran seperti siklus 1 dengan memberi perhatian pada permasalahan yang telah ditemukan pada siklus 1 .

b) Tahap Pelaksanaan

Tahap pelaksanaan siklus II ini dilaksnakan pada tanggal 23 Mei 2013 dengan dibantu teman sejawat sekaligus sebagai pengamat dalam pembelajaran, pada pelaksanaan siklus II, dilakukan sebagai upaya peningkatan kemampuan hasil belajar pada materi Q.S al-Lahab melalui model Pembelajaran Jigsaw bagi siswa kelas V11 D di MTs N 02 Semarang yang didalamnya mengadakan serangkaian kegiatan sebagai berikut:

a. Guru melaksanakan pembelajaran seperti pada siklus 1

b. Memberi kesempatan kepada siswa untuk menemukan dan menerapkan idenya sendiri. disini siswa aktif dengan mengajukan pertanyaan dan siswa yang lain menjawab 
pertanyaan tersebut sedangkan guru hanya membimbing.

c. Guru meningkatkan kegiatan yang belum mendukung keaktifan dan motivasi dalam mengikuti kegiatan pembelajaran materi Q.S al-Lahab.

d. Menyadarkan siswa agar menerapkan strategi mereka sendiri dalam belajar artinya siswa mampu menyerap dan mengaplikasikan materi pelajaran dalam dunia nyata.

c) Tahap Observasi.

Tahap ini guru memberikan penjelasan dari awal sampai terjadinya diskusi antar siswa kemudian siswa mengerjakan soal-soal yang berhubungan dengan materi Q.S al-Lahab, tes formatif ini dilaksanakan pada kegiatan akhir sebagai bahan penulis untuk menganalisis hasil pekerjaan siswa dan mempraktikkan atau mengaplikasikan materi yang yang dipelajari dalam kehidupan sehari-hari.

d) Tahap Refleksi

Berdasarkan hasil pengamatan antara guru dengan guru pamong bahwa pada siklus kedua ini, diperoleh suatu perubahan, yakni peserta didik telah mengadakan diskusi dengan baik sehingga terdapat peningkatan motivasi dan hasil belajar materi Q.S al-Lahab.

\section{Tekhnik Pengumpulan Data}

Dalam penelitian ini peneliti menggunakan beberapa metode pengumpulan data, antara lain: a) Metode Observasi, b) Metode Tes , c.) Metode Dokumentasi, d) Kolabolator, e) Instrumen Penelitian

Instrumen yang peneliti gunakan untuk menilai tingkat keberhasilan peserta didik adalah:

1. Lembar observasi

Lembarobservasiadalahlembarpengamatanyangharusdiisi oleh observer. Lembar observasi berisi aktifitas siswa dalam pembelajaran.

2. Bobot skor yang penilaian:

a. Jika anak tidak termotivasi.

b. Jika anak kurang termotivasi. 

c. Jika anak cukup termotivasi.
d. Jika anak sangat termotivasi.

3. Kriteria Penskoran
a. Skor A : Jika jumlah skornya mulai 13 sampai 16 .
b. Skor B : Jika jumlah skornya mulai 9 sampai 12.
c. Skor C : Jika jumlah skornya mulai 5 sampai 8
d. Skor D : Jika jumlah skornya mulai 1 sampai 4.

4. Instrumen Tes

Instrumen ini digunakan untuk memperoleh bukti yang dapat meyakinkan akan taraf pencapaian tujuan mengajar maka, diperlukan sebuah cara penilaian atau evaluasi yang memenuhi syarat-syarat realibilitas (dapat dipercaya) dan validitas (keabsahan) berupa tes tertulis (pilihan ganda dan Essay).

\section{Simpulan}

Dari hasil perbaikan pembelajaran yang telah dilaksanakan, maka penulis dapat menarik kesimpulan sebagai berikut:

1. Penggunaan motode pembelajaran Jigsaw dapat meningkatkan motivasi belajar siswa pada mata pelajaran Al-Qur'an Hadits materi Q.S. al-lahab dan an-Nashr Kelas VIID di MTsN 02 semarang

2. Metode pembelajaran Jigsaw juga dapat meningkatkan prestasi belajar siswa materi Q.S. al-Lahab dan an-Nashr kelas VII D di MTsN 02 Semarang. 


\section{DAFTAR PUSTAKA}

Ahmadi, Abu. 1990. Psikologi Belajar. Jakarta: Rineka Cipta.

Arikunto, Suharsimi. 2001. Dasar-Dasar Evaluasi Pendidikan. Jakarta: Bumi Aksara. .2006. Prosedur Penelitian Suatu Pendekatan Praktek. Jakarta: Rineka Cipta.

Departemen Agama. 2000. Al-Qur'an dan Terjemahannya. Bandung: CV. Diponegoro.

Departemen Pendidikan Direktorat Jendral Pendidikan Dasar dan Menengah. 2003. Penelitian Tindakan Kelas, Jakarta: Direktorat Tenaga Kependidikan.

Djamarah, Syaiful Bahri. 1994. Prestasi Belajar dan Kompetensi Guru, Surabaya: Usaha Nasional.

Echols, John M. dan Sadily, Hasan. 2000. Kamus Inggris Indonesia. Jakarta: Gramedia.

Falah, Ahmad. 2010. Aspek-aspek Pendidikan Islam. Yogyakarta: Idea Press.

Fathurrohman, M. \& Sulistiyorini. 2012. Belajar dan Pembelajaran. Yogyakarta: Teras, 2012.

Gunarsa, Singgih D. 1978. Pengantar Psiklologi. Jakarta: Mutiara.

Hamidi. 2004. Metode Penelitian Kualitatif. Malang: Universitas Muhammadiyah Malang.

Ibrohim, T. dan Darsono, H. 2009. Penerapan al-Qur'an Hadits, Solo: Tiga Serangkai.

Muhaimin. 2001. Paradigma Pendidikan Islam. Bandung: Remaja Rosda Karya.

Margono. 2004. Metodologi Penelitian Pendidikan. Jakarta: Rineka Cipta.

Nasution. 1982. Didaktik Azas-azas Mengajar. Bandung: Jemmers.

Purwanto, Ngalim. 1998. Psikologi Pendidikan. Bandung: Remaja 
Rosda Karya.

Rahim, Husni. 2005. Wawasan Tugas Guru dan Tenaga Kependidikan. Jakarta: Direktorat Jenderal Kelembagaan Agama Islam.

Syah, Muhibbin. 2010. Psikologi Pendidikan Dengan Pendekatan Baru. Bandung: Remaja Rosda Karya.

Silberman, Melvin L. 2007. Active Learning: 101 Strategi Pembelajaran Aktif. Yogyakarta: Pustaka Insani Madani.

Silberman, Melvin L. 1996. Active Learning 101: Belajar Siswa Aktif. Bandung: Nusamedia.

Sudjana, Nana. 1989. Penelitian dan penilaian peserta didik, Bandung: Sinar Baru.

Sugiono. 2007. Metodologi Penelitian Pendidikan Pendekatan Kuantitatif Kualitatif dan RひDD. Bandung: Alfabeta.

Trianto. 2010. Mendesain Model Pembelajaran Inovatif-Progresif: Konsep, Landasan dan Implementasinya pada Kurikulum Tingkat Satuan Pendidikan (KTSP). Jakarta: Kencana Prenada Media Group.

Wehmeier, Sally. 2000. Oxford Advanced Leaner's Dictionary. New York: Oxford University Press. 
Ani Mardliyah

halaman ini bukan sengaja dikosongkan 